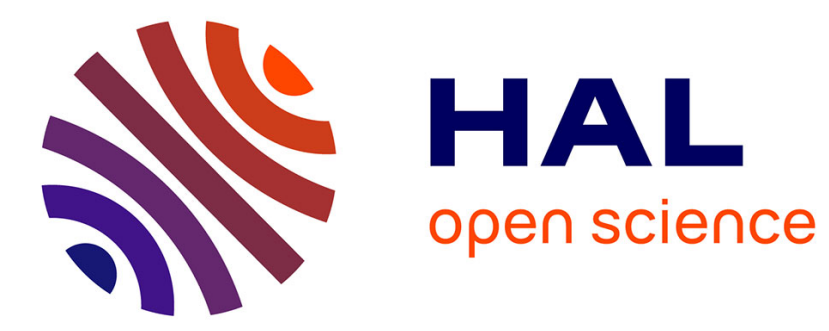

\title{
Peptidases of dairy propionic acid bacteria
}

Valérie Gagnaire, Daniel Mollé, Terje Sorhaug, Joëlle Léonil

\section{To cite this version:}

Valérie Gagnaire, Daniel Mollé, Terje Sorhaug, Joëlle Léonil. Peptidases of dairy propionic acid bacteria. Le Lait, 1999, 79 (1), pp.43-57. hal-00929636

\section{HAL Id: hal-00929636 \\ https://hal.science/hal-00929636}

Submitted on 1 Jan 1999

HAL is a multi-disciplinary open access archive for the deposit and dissemination of scientific research documents, whether they are published or not. The documents may come from teaching and research institutions in France or abroad, or from public or private research centers.
L'archive ouverte pluridisciplinaire HAL, est destinée au dépôt et à la diffusion de documents scientifiques de niveau recherche, publiés ou non, émanant des établissements d'enseignement et de recherche français ou étrangers, des laboratoires publics ou privés. 


\title{
Review
}

\section{Peptidases of dairy propionic acid bacteria}

\section{Valérie Gagnaire ${ }^{\mathrm{a} *}$, Daniel Molléa ${ }^{\mathrm{a}}$ Terje Sørhaug ${ }^{\mathrm{b}}$, Joëlle Léonil ${ }^{\mathrm{a}}$}

\author{
${ }^{\text {a }}$ Laboratoire de recherches de technologie laitière, Inra, 65, rue de Saint-Brieuc, \\ 35042 Rennes cedex, France \\ ${ }^{b}$ Department of Food Science, P.O. Box 5036 Agricultural University of Norway, \\ N-1432 Ås, Norway
}

\begin{abstract}
Although propionic acid bacteria dominate Swiss-type cheeses, with populations reaching $\sim 10^{9}$ colony forming units per $g$ of cheese after the warm room ripening period, their role in proteolysis is far from being as well established as that of the lactic acid bacteria. This review will focus on the localization and biochemical characteristics of the peptidases of dairy propionic acid bacteria. Using peptide substrates related to those encountered in cheese and electrospray ionization mass spectrometry analysis, the action of carboxypeptidase(s) in addition to that of aminopeptidase(s), $\mathrm{X}$-prolyl dipeptidyl aminopeptidase and endopeptidase(s) are clearly shown. Finally, the potential role of the propionic acid bacteria in Swiss-type cheese proteolysis is discussed. (c) Inra/Elsevier, Paris.
\end{abstract}

propionic acid bacteria / proteolysis / peptidase / Swiss-type cheese / ripening

Résumé - Les peptidases des bactéries propioniques. Bien que les bactéries propioniques représentent une flore dominante des fromages à pâte pressée cuite, avec une population pouvant atteindre environ $10^{9}$ unités formant colonie par gramme de fromage pendant l'affinage en cave chaude, leur rôle dans la protéolyse au cours de l'affinage est encore loin d'être établi comparativement à celui des bactéries lactiques. Cette revue est consacrée aux peptidases des bactéries propioniques, à leur localisation et à leurs caractéristiques biochimiques. L'utilisation de substrats peptidiques proches de ceux rencontrés dans le fromage et l'identification par spectrométrie de masse à source d'ionisation electrospray des produits issus de l'hydrolyse, par les peptidases de quatre souches de bactéries propioniques, nous a permis de montrer clairement l'action de carboxypeptidase(s), en complément de celles d'aminopeptidase(s), X-prolyl dipeptidyl aminopeptidase et endopeptidase(s). Enfin, nous discuterons le rôle potentiel des bactéries propioniques dans la protéolyse des fromages à pâte pressée cuite. (C) Inra/Elsevier, Paris.

bactérie propionique / protéolyse / peptidase / fromage à pâte pressée cuite / affinage

Oral communication at the 2nd Symposium on Propionibacteria, Cork, Ireland, June 25-27, 1998.

* Correspondence and reprints. gagnaire@ labtechno.roazhon.inra.fr 


\section{INTRODUCTION}

Besides the propionic acid fermentation which, in Swiss-type cheeses, leads to the production of typical flavour (acetate and propionate) and $\mathrm{CO}_{2}$, responsible for the formation of the eyes in the cheese, proteolysis is the main factor in ripening and flavour development [39]. A complex process of casein breakdown into peptides and amino acids occurs during ripening through the catalytic action of several proteolytic agents: milk coagulant, indigenous milk proteinase (plasmin), starter, non-starter and secondary starter proteinases and peptidases.

In hard cooked cheeses, the indigenous milk proteinase, plasmin, is mainly responsible for the primary hydrolysis of the caseins since the coagulant, rennet, is almost completely inactivated during cooking and has only a weak action on the caseins [3]. The main peptides identified in Parmigiano Reggiano [1, 2] and in Grana Padano [13] clearly showed the prominent action of plas$\min$ on $\beta$ - and $\alpha_{\mathrm{s} 2}$-caseins as well as the recurrent action of aminopeptidases and carboxypeptidases of the microflora.

Several studies have reported an essential role for the proteolytic agents from the starter lactic acid bacteria (LAB) in Swisstype cheese $[15,39]$. By comparing experimental cheeses manufactured with aminopeptidase deficient mutant strains of $L b$. helveticus or the parental strain as starter, Prost and Chamba [32] showed that the enzymic system of this species can account for one-third of the aminopeptidase activity found in cheese. Recently, general aminopeptidase and $\mathrm{X}$-prolyl dipeptidyl aminopeptidase (PepX) activities from thermophilic starters were shown to be prominent in Emmental juice extracted before the secondary flora, which is mainly composed of propionic acid bacteria (PAB), grows [16].

Dairy PAB are the dominant flora in Swiss-type cheeses and reach numbers of $\sim 10^{9}$ colony forming units (cfu) per g of cheese after the warm room ripening period. However, their role in the proteolytic process is not at all as clear as that of the LAB ([15], [39]).

The proteinases of $\mathrm{PAB}$ have been recently reviewed by Langsrud et al. [21], and appear to be of modest importance in the breakdown of caseins. Indeed, dairy PAB grow slowly in milk [3], rendering their growth in cheese dependent on the primary hydrolysis of caseins by LAB during ripening. In contrast, dairy $\mathrm{PAB}$ have high peptidase activities [34] suggesting they may be involved in the hydrolysis of peptides produced from caseins.

The localization and biochemical characteristics of peptidases of dairy PAB, including new results on their substrate specificities, will be reviewed and compared with $L A B$ peptidases.

\section{PAB PEPTIDASES}

\subsection{Detection of peptidase activity}

Various peptidase activities have been detected in dairy PAB (table I). Sahlström et al. [34] found that most of the peptidase activities present in two strains of $P$. freudenreichii subsp. shermanii were mainly located intracellularly. Of the 6 to 7 peptidase bands detected, one was associated with the cell wall, while two or three were associated with the membrane. Carboxypeptidase activity was reported by Sahlström et al. [35] and two different enzymes isolated from the cell wall of two P. freudenreichii strains. El Soda et al. $[9,10]$ also studied the intracellular peptidase system of Propionibacterium and found that the seven strains studied contained aminopeptidase, dipeptidase and caseinolytic activity. Floberghagen et al. [14] showed that PAB strains have a wide range of substrate specificities with high activity on dipeptides and peptides containing Pro or Phe as the $\mathrm{N}$-terminal amino acid. Such a high activity on N-terminal aromatic amino acids, especially towards 
Table I. Peptidase activities detected in dairy PAB. Purified enzymes are shown in table II.

Tableau I. Activités peptidasiques détectées chez les bactéries propioniques laitières. Les enzymes purifiées sont présentées dans le tableau II.

\begin{tabular}{|c|c|c|c|c|}
\hline Strains & Substrate used & Proteolytic activity tested & Location & References \\
\hline $\begin{array}{l}\text { P. shermanii } \alpha \text { and } \mathrm{FSCN} \\
\text { P. pentosaceum ATCC } 4875 \\
\text { P. arabinosum ATCC } 4965 \\
\text { P. shermanii ATCC } 9614\end{array}$ & $\begin{array}{l}33 \text { dipeptides including Pro- } X \\
\text { and Phe- } X \text { peptides }\end{array}$ & $\begin{array}{l}\text { dipeptidase activity and enzymes acting } \\
\text { specifically on Pro-X peptides and others } \\
\text { on Phe at the amino end }\end{array}$ & intracellular & [14] \\
\hline $\begin{array}{l}\text { P. freudenreichii subsp. } \\
\text { shermanii ATCC } 9614 \\
\text { P. freudenreichii subsp. } \\
\text { shermanii INF } \alpha\end{array}$ & $\begin{array}{l}15 \text { dipeptides } \\
3 \text { tripeptides }\end{array}$ & dipeptidases and tripeptidases & $\begin{array}{l}\text { cell-wall, intracellular, } \\
\text { membrane }\end{array}$ & [34] \\
\hline $\begin{array}{l}\text { P. freudenreichii subsp. } \\
\text { shermanii } \mathrm{ATCC} 13673 \text { and } \mathrm{E}_{2} 2 \\
\text { P. freudenreichii subsp. freudenreichii GP6 } \\
\text { P. acidipropionici } \mathrm{ATCC} 4875 \text { and } 11 \\
\text { P. jensenii } \mathrm{ATCC} 4869 \\
\text { P. thoenii ATCC } 4874\end{array}$ & $\begin{array}{l}\text { Leu-pNA } \\
\text { Pro-pNA }\end{array}$ & Leucyl aminopeptidase and proline & $\begin{array}{l}\text { intracellular } \\
\text { iminopeptidase }\end{array}$ & [30] \\
\hline P. shermanii NZ & pNA derivatives & aminopeptidase dipeptidyl aminopeptidase & intracellular & [9] \\
\hline $\begin{array}{l}\text { P. freudenreichii CNRZ23, } \\
\text { CNRZ82, AU59 and AU722 }\end{array}$ & & & intracellular & \\
\hline $\begin{array}{l}\text { P. acidipropionici CNRZ80 } \\
\text { P. jensenii CNRZ87 }\end{array}$ & $\begin{array}{l}\text { pNA derivatives dipeptides } \\
\text { whole casein }\end{array}$ & $\begin{array}{l}\text { aminopeptidase } \\
\text { caseinolytic activity }\end{array}$ & & {$[10]$} \\
\hline
\end{tabular}


Table I. (continued) / Tableau I. (suite).

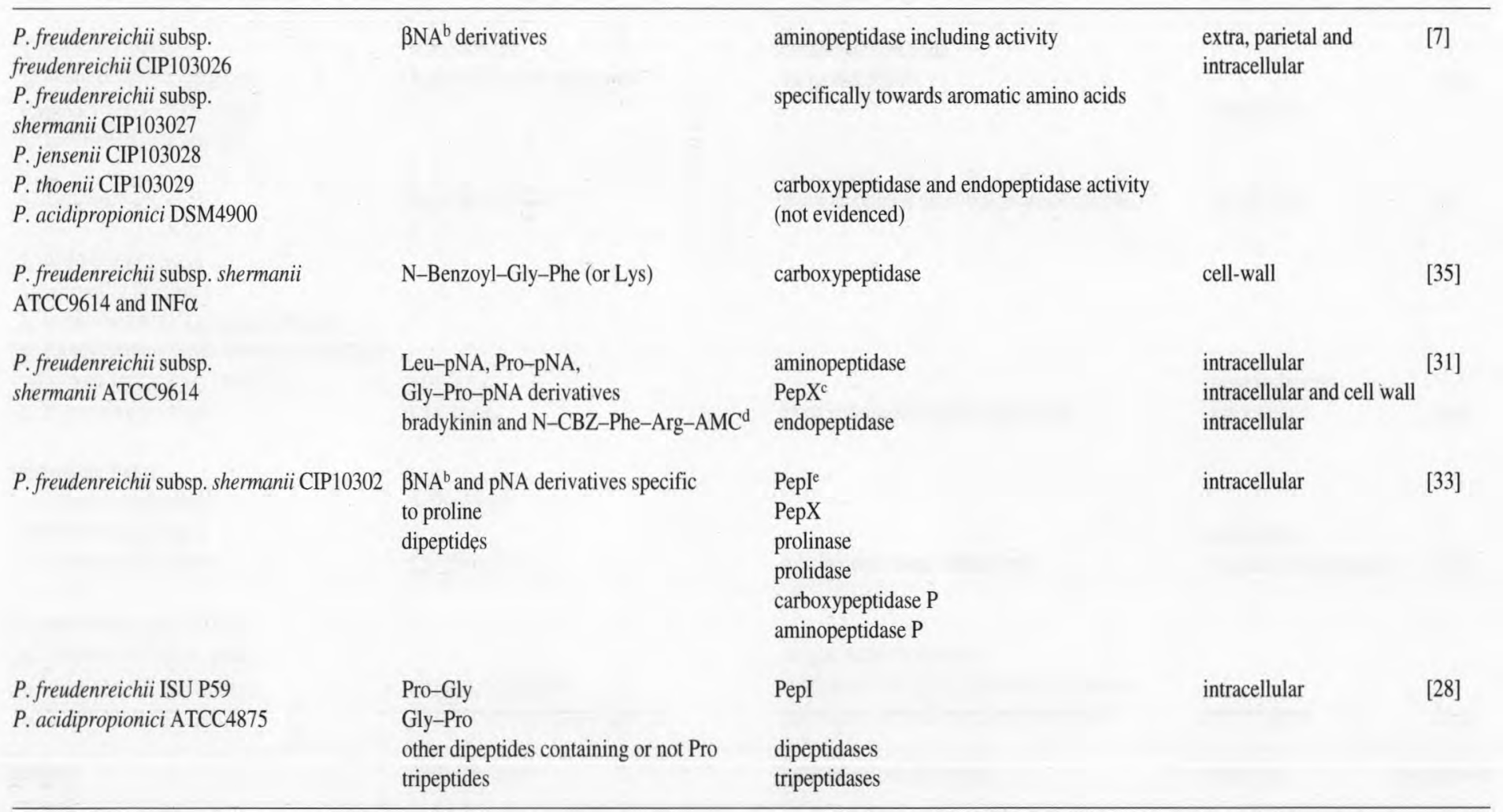

${ }^{a} \mathrm{pNA}$, amino acid or peptides para-nitroanilide derivatives $/{ }^{\mathrm{a}} \mathrm{pNA}$, dérivés para-nitroanilides de peptides ou d'acides aminés.

${ }^{\mathrm{b}} \beta \mathrm{NA}$, amino acid or peptides $\beta$-naphthylamides derivatives / ${ }^{\mathrm{b}} \beta \mathrm{NA}$, dérivés $\beta$-naphthylamides de peptides ou d'acides aminés.

${ }^{c}$ PepX, X-prolyl dipeptidyl aminopeptidase activity / c PepX, activité X-prolyl dipeptidyl aminopeptidase.

${ }^{\mathrm{d}} \mathrm{AMC}$, amido-4-methyl-coumarin / ${ }^{\mathrm{A}} \mathrm{AMC}$, amido-4-methyl-coumarine.

${ }^{\mathrm{e}} \mathrm{PepI}$, proline iminopeptidase / ${ }^{\mathrm{e}} \mathrm{PepI}$, proline iminopeptidase. 
Phe, was also found in two other P. freundenreichii strains [7]. Leucine-aminopeptidase activity was found in each of four dairy PAB species, $P$. freudenreichii (including subspecies freudenreichii and shermanii), $P$. acidipropionici, $P$. jensenii and $P$. thoenii [30].

Because of the high proline concentration found in Swiss-type cheese, most attention has been paid to activities cleaving peptide bonds involving proline. This has been attributed to proteolytic activity of PAB by Langsrud et al. [19, 20]. Proline iminopeptidase (PepI) and PepX activities were described by several authors $[10,12,27,30$, 31, 33]. Quelen et al. [33] have reported prolinase and prolidase activities, but have not found carboxypeptidase or endopeptidase activities specific for proline.

\subsection{Purification and characterization of the peptidases}

Table II summarizes the characteristics of the peptidases that have been purified from dairy $\mathrm{PAB}$.

\subsubsection{Aminopeptidases}

Among the peptidases, PepI in cell-free extracts of $P$. shermanii 13673 was the first enzyme to be purified [29]. The enzyme was inhibited by phenylmethylsulfonyl fluoride suggesting it was a serine enzyme and by ethylene-diamine-tetra acetic acid (EDTA) indicating a requirement for metal ions. This peptidase hydrolysed specifically Pro-pNA and dipeptides, but only if they had a proline residue in the $\mathrm{N}$-terminal position (such as Pro-Met, Pro-Phe, Pro-Leu, Pro-Ile and Pro-Gly) and the $\beta$-casomorphin des-Tyr fragment 7 . The gene encoding PepI has been cloned [46] and the intracellular localization of the protein confirmed.

In $P$. freudenreichii subsp. freudenreichii CIP103026, two fractions active towards Phe with closely related characteristics (molecular weight of $69 \mathrm{kDa}$, optimum activity at $\mathrm{pH} 7.5$ and $37^{\circ} \mathrm{C}$ ) were found [7]. Both are metallo-enzymes which are also inactivated by thiol inhibitors, indicating probable requirement for a thiol group for activity.

The Leu-aminopeptidase activity [30] has been partially purified by El Soda et al. [9].

\subsubsection{Dipeptidylaminopeptidase and dipeptidases}

It is only very recently that PepX from $P$. freudenreichii subsp. shermanii NCDO 853 has been purified by a combination of diethyl-amino-ethyl (DEAE) chromatography, hydrophobic interaction chromatography and chromatofocusing [11]. This intracellular enzyme, with a molecular mass of $84 \mathrm{kDa}$, is a serine protease inhibited by metals, such as $\mathrm{Cu}^{2+}$. It is active at acid pH values with $95 \%$ of maximal activity at $\mathrm{pH} 5.5$, whereas the PepX from most Lactobacillus and Lactococcus species have a $\mathrm{pH}$ optimum close to neutrality.

Sahlström et al. [35] purified two cellwall peptidases, one from $P$. freudenreichii subsp. shermanii ATCC 9614 with a Rf value in PAGE of 0.57 , and another from $P$. freudenreichii subsp, shermanii INF- $\alpha$. with a $\mathrm{Rf}$ of 0 . They could potentially represent the first breakdown step of casein peptides originating outside the cell [35]. Both are metallo-enzymes, with thiol groups at the active site. Their molecular masses determined by gel filtration, were 82 and $134 \mathrm{kDa}$ for Rf 0 and Rf 0.57 , respectively. These cell wall peptidases hydrolyse Pro-Phe as well as N-terminal blocked peptides (N-benzoyl-Gly-Phe and N-benzoyl-Gly-Lys) suggesting a carboxypeptidase activity, but have little or no aminopeptidase activity on Leu-pNA, LyspNA and Ala-pNA. Carboxypeptidase activity has been rarely described in LAB except by El Soda et al. [8] for Lactobacillus casei. 
Table II. Characteristics and localization of the peptidases purified from dairy PAB.

Tableau II. Caractéristiques et localisation des peptidases purifiées chez les bactéries propioniques laitières.

\begin{tabular}{|c|c|c|c|c|c|c|c|c|c|}
\hline Enzyme & Substrate & Strain & Purification & $\begin{array}{l}\mathrm{Mw} \\
\mathrm{kDa}\end{array}$ & $\begin{array}{l}\text { Quaternary } \\
\text { structure }\end{array}$ & Type & $\underset{\mathrm{pH}}{\text { Optimum I }}$ & Location $\mathrm{F}$ & References \\
\hline PepI & $\operatorname{Pro} \downarrow X-(X)_{n}$ & P. shermanii 13673 & $\begin{array}{l}\text { homogeneity } \\
\text { cloned }\end{array}$ & $61^{*}$ & Mono & $S$ & 8.0 & intra & $\begin{array}{l}{[29]} \\
{[46]}\end{array}$ \\
\hline PepX & $\mathrm{X}-\operatorname{Pro\downarrow }(\mathrm{X})_{n}$ & P. shermanii NCDO853 & & $84^{*+}$ & Mono & S & $5.5-7.5$ & intra? & [11] \\
\hline Aminopeptidase & $\begin{array}{l}\text { Leu } \downarrow X-(X)_{n} \\
\text { Lys } \downarrow X-(X)_{n}\end{array}$ & P. shermanii $\mathrm{NZ}$ & partial & ND & ND & M & \# 7.0 & intra & [9] \\
\hline Dipeptidyl aminopeptidase & Gly-Pro $\downarrow(X)_{n}$ & P. shermanii $\mathrm{NZ}$ & partial & ND & ND & $S$ & \# 7.0 & intra & \\
\hline Phenylalanine aminopeptidase & Phe- $\downarrow X-(X)_{n}$ & $\begin{array}{l}\text { P. freudenreichii subsp. } \\
\text { freudenreichii CIP103026 }\end{array}$ & homogeneity & $69^{*}$ & Mono & $\mathrm{C}$ & 7.5 & intra & [7] \\
\hline \multirow[t]{2}{*}{$\begin{array}{l}\text { Peptidases/ } \\
\text { carboxypeptidases }\end{array}$} & $\begin{array}{l}\text { Pro-Phe and } \\
\text { N-Benzoyl-Gly-Phe (or Lys) }\end{array}$ & $\begin{array}{l}\text { P. freudenreichii subsp. } \\
\text { shermanii ATCC9614 (Rf 0.57) }\end{array}$ & partial & $134^{+}$ & ND & M & 8.6 & cell wall & [35] \\
\hline & & $\begin{array}{l}\text { P. freudenreichii subsp. } \\
\text { shermanii INF } \alpha(\operatorname{Rf} 0)\end{array}$ & partial & $82^{+}$ & ND & M & 10.0 & cell wall & \\
\hline Endopeptidase & $\begin{array}{l}\text { bradykinin } \\
\text { casein } \\
\text { Met-enkephalin } \\
\text { angiotensin I } \\
\alpha_{\mathrm{s} 1} \mathrm{CN}(1-23)\end{array}$ & P. freudenreichii АТCС 9614 & homogeneity & $44^{+}$ & Mono & M & $6.5-8.0$ & intra & {$[44]$} \\
\hline Oligopeptidase & $\begin{array}{l}\text { bradykinin } \alpha_{\mathrm{sl}} \mathrm{CN}(1-23) \\
\alpha_{\mathrm{sl}} \mathrm{CN}(165-199) \\
\text { oxidized } \beta \text {-chain insulin }\end{array}$ & P. freudenreichii ATCC9614 & homogeneity & $67^{*}$ & Mono & M & $6.7-7.5$ & intra & [40] \\
\hline Oligopeptidase & bradykinin, peptides $<17$ aa & P. freudenreichii ATCC 9614 & homogeneity & $33^{*}$ & Tetra & M & $6.7-7.5$ & intra & [41] \\
\hline
\end{tabular}

Mw, Molecular weight determined by SDS-PAGE (*) or/and by gel filtration (+); intra, intracellular; S, serine protease; M, metalloprotease; C, cystein protease; ND, not determined; $\downarrow$ hydrolysis site.

Mw, masse moléculaire déterminée par SDS-PAGE $(*)$ ou/et par gel filtration $(+)$; S, sérine protease ; M, métalloprotease ; C, cystéine protease ; ND, non déterminé ;

$\downarrow$ site de coupure de l'enzyme. 


\subsubsection{Endopeptidases}

One endopeptidase [44] and two oligopeptidases [40, 41] from the cytosol of $P$. freudenreichii ATCC 9614 have been purified and characterized at the Agricultural University of Norway. The endopeptidase has been purified to homogeneity [44] using four chromatographic steps: anionexchange on Fast Flow Q Sepharose, hydroxyapatite, a second anion exchange on MonoQ and gel filtration on Superose 12. This endopeptidase is a metallo-enzyme, inhibited more by EDTA than by 1,10 -phenanthroline and is not sensitive to phosphoramidon. The molecular mass is $44 \mathrm{kDa}$, which is lower than that of LAB endopeptidases.

This endopeptidase is highly active on bradykinin and peptides containing between 5 and 23 amino acid residues, but it had low activities on peptide substrates of higher chain length (oxidized insulin $\beta$-chain, 30 amino acid residues, or casein). The endopeptidase showed an interesting tendency to cleave peptide bonds containing Pro and/or Phe. It also has different specificities compared to the endopeptidases from $\mathrm{LAB}$, e.g. the PepO, from Lc. lactis subsp. cremoris $\mathrm{Wg} 2$ which hydrolyses oligopeptides containing 5 (metenkephalin) to 30 (oxidized insulin $\beta$-chain) amino acid residues, but not casein [42]; PepF from Lc. lactis which hydrolyses peptides containing 7 to 17 amino acids with a rather broad specificity [26] and the PepF from $L b$. helveticus which has a broad specificity for peptides of 3 to 34 amino acid residues [37].

The oligopeptidase, purified by Stepaniak et al. [40], is a monomer with a molecular mass of $67 \mathrm{kDa}$ and is strongly inhibited by metal chelators and partially by $p$-chloromercuribenzoate and by $\beta-\mathrm{CN}$ $(58-72)$. This enzyme is highly active on bradykinin, has maximum activity in the $\mathrm{pH}$ range $6.7-7.5$ and at a temperature of $40^{\circ} \mathrm{C}$; more than $20 \%$ of the maximum activity is retained at $7{ }^{\circ} \mathrm{C}$ and at $\mathrm{pH} 5.5$, i.e. under conditions which simulate cheese. It is also active on other peptides, such as $\alpha_{s 1}-C N$ (1-23), $\alpha_{\mathrm{s1}}-\mathrm{CN}(165-199)$ and towards the oxidized $\beta$-chain of insulin. The substrate specificity differs from the $44-\mathrm{kDa}$ oligopeptidase of $P$. freudenreichii ATCC 9614 mentioned above.

The other oligopeptidase [41] has the same $\mathrm{pH}$ and temperature optima and activity at $7{ }^{\circ} \mathrm{C}$ and $\mathrm{pH} 5.5$. However, it differs from the $67-\mathrm{kDa}$ one in having a tetrameric structure of 4 subunits, each of $33 \mathrm{kDa}$, and in its substrate specificity. The activity is mainly directed towards peptides containing 7 to 11 amino acids, e.g. bradykinin and substance $P$ and less towards peptides with higher or lower numbers of amino acids.

Both endopeptidase and the $67-\mathrm{kDa}$ oligopeptidase, but not the 33-kDa oligopeptidase, cleave $\alpha_{s}-\mathrm{CN}(1-23)$ with somewhat different specificity $[40,41,44]$. There is convincing evidence for endo/oligopeptidase activity in P. freudenreichii although activities were not observed in other studies with $p$-nitroanilide and $\beta$-naphthylamide derivatives $[7,10]$.

\section{INVOLVEMENT OF THE PEPTIDASES OF DAIRY PAB IN SWISS- TYPE CHEESE RIPENING}

In Swiss-type cheeses, peptides released by rennet, plasmin and enzymes of the thermophilic starter bacteria can be further degraded and utilized by PAB. However, peptides and amino acids also contribute to cheese flavour, directly as peptides and free amino acids or indirectly as products of amino acid catabolism [4]. Except for the production of proline which is associated with the sweet and nutty flavour of Emmental cheese $[19,20]$, only little information is available on the role of dairy PAB in proteolysis during ripening. This is due to the fact that the peptides present in cheese, which can be degraded by $\mathrm{PAB}$ peptidases, 
have not been identified, and whether or not $\mathrm{PAB}$ can lyse and liberate their intracellular peptidases in cheese curd.

\subsection{Variability and substrate specificities of peptidases}

The diverse proteolytic activities of $\mathrm{PAB}$ have been clearly shown to be strain and species dependent. Among the peptidases, aminopeptidases with activities towards leucyl or prolyl residues, PepX activity and endo-oligopeptidases have received the most attention.

Variability in the general aminopeptidase and PepI activities in the four species of dairy PAB have been observed with 10 times more activity in $P$. jensenii and $P$. freudenreichii than in $P$. acidipropionici and $P$. thoenii [30]. Differences in the specific activity of the two enzymes have also been shown. The PepI activity was higher than that of Leu-aminopeptidase as determined by using Pro- and Leu-pNA derivatives respectively $[9,10,29,30]$. When the PepI activity is compared within the genus Propionibacterium, it is generally highest for $P$. freudenreichii $[7,30]$. In contrast, in $\mathrm{LAB}$, the action of the general aminopeptidase is more important than that of PepI [31]. Tobiassen et al. [45] reported that the general aminopeptidase activity of $\mathrm{Lb}$. helveticus INF-II was 5 times higher than that of $P$. freudenreichii INF- $\alpha$.

PepI activity is more important than PepX activity in all the strains of the four dairy PAB studied [7, 9, 10, 29, 31, 33]. The former activity was at least 10 times higher than the latter $[31,33]$. The reverse is true for LAB [36].

Concerning the other types of intracellular peptidases, activity towards Phe- $\beta$ NA, Trp- $\beta$ NA and Tyr- $\beta$ NA was higher in the two strains of $P$. freudenreichii than in strains of $P$. thoenii, $P$. jensenii and $P$. acidipropionici [7]. This enzyme appears to be specific for aromatic amino acids and seems to be present in PAB but not in LAB.
However, comparison of the peptidase activities in strains of dairy $\mathrm{PAB}$ and their potential role in cheese ripening is rather difficult because: i) specificities of these enzymes on peptides present in cheese have not been explored systematically; ii) the substrates used were largely confined to amino acid and peptides derivatives of paranitroanilides and $\beta$-naphthylamides which may have a limited relationship to the peptides found in cheese; and iii) the assay conditions ( $\mathrm{pH}$, temperature, etc.) generally did not reflect the conditions prevailing during cheese ripening.

In a recent study, a more general approach with a tryptic/chymotryptic hydrolysate of $\beta$-casein as substrate was used to determine peptidase activity in cell-free extracts from 37 strains of $\mathrm{PAB}$ at a $\mathrm{pH}$ (5.7) simulating ripening in Swiss-type cheese [22]. All the strains were able to hydrolyse peptides from $\beta$-casein; however, differences in proteolytic activity were observed between and within the four species of dairy PAB. Two groups could be distinguished: one group with high peptidase activity containing four strains of $P$. freudenreichii subsp. freudenreichii (TL213, I, K, TL504B) and one of P. freudenreichii subsp, shermanii CIP103027, which agrees with results previously reported with chromogenic substrates, and the second group with slower activity containing two strains each of $P$. jensenii (CIP103028 and TL222) and P. freudenreichii subsp. freudenreichii (TL504A and TL512).

In addition, large variations in the free amino acids released by the strains were observed, ranging from $7 \%$ of the total amino acid content of the $\beta$-casein for $P$. jensenii TL222 to $24 \%$ for $P$. freudenreichii subsp. shermanii CIP103027 [22]. The strains also differed in the nature of the free amino acids released, e.g. Asp and/or Asn were released by only 5 out of 14 strains of $P$. freudenreichii subsp. freudenreichii, $P$. jensenii and $P$. thoenii, lle was not released by 5 out of 14 strains (three $P$. freu- 
denreichii and two $P$. jensenii) and Gly by 3 out of 14 strains (two $P$. freudenreichii and one $P$. acidipropionici).

This means that different substrate specificities of the peptidases exist depending on the strains. However, until now, little is known about the nature of the peptides hydrolysed by PAB peptidases. This fact prompted us to identify the peptides generated from $\beta$-casein by the cell-free extracts of PAB. On-line liquid chromatography (LC) coupled with electrospray-ion source mass spectrometry (ESI-MS) allowed us to determine the molecular mass of each peptide and, collision-induced dissociation using tandem mass spectrometry allowed their sequence to be determined. Figure $1 A$ shows the peptides initially produced from $\beta$-casein by trypsin and chymotrypsin and figure $I B-E$ those produced after $24 \mathrm{~h}$ hydrolysis of the tryptic/chymotryptic digest by the cell-free extracts of dairy PAB.

A number of peptides of different length with the recurrent loss of one or more residues from the $\mathrm{N}$ - or $\mathrm{C}$-terminal ends, indicating activity of aminopeptidase and carboxypeptidase, respectively. Val, Leu/Ile and Ala as well as the aromatic amino acids, Tyr and Phe, were released from the $\mathrm{N}$-terminal extremity of the peptides, suggesting the action of an aminopeptidase with broad specificity or the combined action of a general aminopeptidase and another one specific for aromatic residues. The release of Phe from the $\mathrm{C}$-terminus agrees with a high proportion of free Phe released by the action of PAB cell-free extracts, as previously determined [22], and clearly shows the presence of carboxypeptidase activity which was also directed towards Leu, Arg, Lys and Pro. Sahlström et al. [35] found carboxypeptidase activity in PAB which released $\mathrm{Phe}$ and Lys from $\mathrm{N}$-terminal blocked peptides (N-benzoyl-Gly-Phe and $\mathrm{N}$-benzoyl-Gly-Lys). The present work expands on the specificity of carboxypeptidase activity in PAB.

We also observed the release of X-Pro peptides from the $\mathrm{N}$-terminal part of some peptides such as Gln-Pro from $\beta-\mathrm{CN}$ (195-201/202) to form $\beta-\mathrm{CN}(197-201 / 202)$ for all the strains, corresponding to a PepX activity. Regardless of the species, peptide $\beta-\mathrm{CN}(69-93)$ was split at bond $\mathrm{Pro}_{86}-\mathrm{Phe}_{87}$ suggesting endopeptidase activity, corresponding to the specificity on bradykinin of endopeptidase and oligopeptidase from $P$. freudenreichii $[41,44]$.

Interestingly, concomitant action of several types of peptidases were essential for hydrolysing the tryptic/chymotryptic peptides of $\beta$-casein. Four types of peptidase activities seem to be required: general aminopeptidase(s), PepX, endopeptidase(s) and carboxypeptidase. For example, $P$. thoenii CIP103029 hydrolysed the peptide $\beta-\mathrm{CN}(59-68)$ into $\beta-\mathrm{CN}(60-67)$ using both an aminopeptidase active on $\mathrm{Val}$ and a carboxypeptidase active on Asn. We can hypothesize that $\beta-\mathrm{CN}(60-67)$ was further hydrolysed into $\beta-C N(62-67)$ by PepX activity releasing Tyr-Pro, instead of the repeated action of aminopeptidase since no $\beta-\mathrm{CN}(61-67)$ was observed.

From the same initial pool of tryptic/chymotryptic peptides of $\beta$-casein, some common bonds were hydrolysed and peptides such as $\beta-C N(69-86), \beta-C N(75-85)$, $\beta-C N(115-118), \beta-C N(129-139)$ and $\beta-\mathrm{CN}(195-202)$ were produced by all strains, while other peptides were hydrolysed by the extracts of only one, two or three of the four strains studied. In contrast, irrespective of the species, it appears that the peptides containing phosphoseryl residues $(\beta-\mathrm{CN}(1-25), \beta-\mathrm{CN}(33-48)$ and $\beta-\mathrm{CN}$ (33-52)) were not hydrolysed. These peptides also seem to be resistant to hydrolysis in other kinds of cheeses: Parmigiano Reggiano [1, 2], Grana Padano [13] and Cheddar [38]. In the case of PAB, they apparently do not possess sufficient phosphatase activity to remove phosphate from the phosphoseryl residues and allow their subsequent hydrolysis by peptidases. 


\subsection{Autolysis of PAB and impact of the peptidases released on the secondary proteolysis in Swiss-type cheese}

As discussed already, PAB peptidases are mainly located intracellularly. To have a direct effect on proteolysis, the release of these intracellular peptidase activities in cheese during ripening requires an autolytic mechanism, which is induced either physiologically or by environmental conditions [25].

The autolysis of $\mathrm{PAB}$ was studied by several authors $[19,20,23,24,27,28]$. Langsrud et al. $[19,20]$ have observed a correlation between autolysis and the production of free proline in milk or modified

Figure 1. Identity of the peptides produced after $24 \mathrm{~h}$ hydrolysis of the tryptic/chymotryptic hydrolysate of $\beta$-casein by the cell-free extracts of the four dairy propionibacteria species. A) Initial tryptic/chymotryptic $\beta$-casein hydrolysate. B, C, D and E) correspond to the peptides present after $24 \mathrm{~h}$ hydrolysis by the cell-free extracts of $P$. freudenreichii subsp. freudenreichii CIP103026, $P$. jensenii CIP103028, $P$. thoenii CIP103029 and $P$. acidipropionici TL249, respectively. $\beta$-Casein $\left(10 \mathrm{~g} \cdot \mathrm{L}^{-1}\right.$ in sterile distilled water) was first hydrolysed by a mixture of trypsin ( $5000 \mathrm{~K}$, Novo Industry A/S, Copenhagen, Denmark) and chymotrypsin (Sigma, Saint-Quentin Fallavier, France), both at an enzyme/substrate ratio of $1: 1000(\mathrm{w} / \mathrm{w})$. The $\mathrm{pH}$ was maintained at 7.2 by adding $0.5 \mathrm{~mol} \cdot \mathrm{L}^{-1} \mathrm{NaOH}$ for $3 \mathrm{~h}$ at $37^{\circ} \mathrm{C}$. Then, the enzymes were inactivated by heating at $80^{\circ} \mathrm{C}$ for $20 \mathrm{~min}$. The $\beta$-casein hydrolysate was freeze-dried and stored at $4{ }^{\circ} \mathrm{C}$ until use. The hydrolysis of this tryptic/chymotryptic digest of $\beta$-casein by the cell-free extract of $\mathrm{PAB}$ was performed at $30^{\circ} \mathrm{C}$ in $50 \mathrm{mmol} \cdot \mathrm{L}^{-1}$ sodium phosphate buffer at $\mathrm{pH} 5.7$ for $24 \mathrm{~h}$ containing $0.7 \mathrm{mg}$ of freeze-dried $\beta$-casein peptides $\cdot \mathrm{mL}^{-1}$ and $137.5 \mu \mathrm{g}$ intracellular protein. The reaction was stopped by heating at $100{ }^{\circ} \mathrm{C}$ in a water bath for $10 \mathrm{~min}$. The samples were analysed by reverse-phase HPLC coupled on-line with electrospray ionization mass spectrometry and the molecular masses determined. Each peak was collected and sequenced by collision-induced dissociation using tandem mass spectrometry as described by Gagnaire et al. [17]. The conditions of elution on RP-HLPC were the same as described by Lemée et al. [22]. In the sequence of $\beta$-casein U corresponds to phosphorylated serine residues. ( $\square$ ) corresponds to the peptides produced by the action of trypsin and chymotrypsin and (-) to those resulting from the action of the peptidases of PAB. $\nabla$, chymotrypsin; $\nabla$, trypsin action

Figure 1. Identité des peptides produits après $24 \mathrm{~h}$ d'hydrolyse de l'hydrolysat trypsique/chymotrypsique de caséine $\beta$ par les extraits intracellulaires des quatre espèces laitières de bactéries propioniques. A) Hydrolysat trypsique/chymotrypsique de caséine $\beta$ initial ; B, C, D et E) correspondent aux peptides présents après $24 \mathrm{~h}$ d'hydrolyse en présence respectivement d'extrait intracellulaire de $P$. freudenreichii subsp. freudenreichii CIP103026, P. jensenii CIP103028, P. thoenii CIP103029 et de $P$. acidipropionici TL249. La caséine $\beta, 10 \mathrm{~g} \cdot \mathrm{L}^{-1}$ d'eau distillée stérile, était initialement hydrolysée par un mélange de trypsine $(5000 \mathrm{~K}$, Novo Industry A/S, Copenhague, Danemark) et de chymotrypsine (Sigma, Saint-Quentin Fallavier, France), chacune avec un rapport enzyme/substrat de $1: 1000(\mathrm{p} / \mathrm{p})$, à pH 7,2 maintenu constant par addition de $\mathrm{NaOH} 0,5 \mathrm{~mol} \cdot \mathrm{L}^{-1}$ pendant $3 \mathrm{~h}$ à $37^{\circ} \mathrm{C}$. Puis les enzymes étaient inactivées par chauffage à $80^{\circ} \mathrm{C}$ pendant $20 \mathrm{~min}$. L'hydrolysat ainsi obtenu était lyophilisé et conservé à $4{ }^{\circ} \mathrm{C}$ jusqu'à utilisation. Les conditions d'hydrolyse de l'hydrolysat trypsique/chymotrypsique de caséine $\beta$ par les extraits intracellulaires de bactéries propioniques

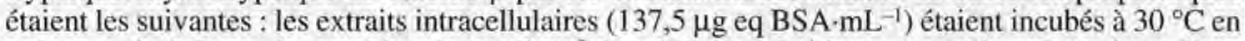
présence de $0,7 \mathrm{mg}$ de peptides de caséine $\beta$ lyophilisés $\cdot \mathrm{mL}^{-1}$ de tampon phosphate de sodium $50 \mathrm{mmol} \cdot \mathrm{L}^{-1}$ à $\mathrm{pH} 5,7$ pendant $24 \mathrm{~h}$. La réaction était arrêtée par chauffage dans un bain-marie à $10{ }^{\circ} \mathrm{C}$ pendant $10 \mathrm{~min}$. Les échantillons étaient analysés par CLHP de phase inverse couplée au spectromètre de masse à source d'ionisation electrospray et les masses moléculaires étaient ainsi déterminées. Chaque pic était collecté puis séquencé par fragmentation au moyen du spectromètre de masse selon les conditions décrites par Gagnaire et al. [17]. Les conditions d'élution en CLHP de phase inverse étaient les mêmes que celles utilisées par Lemée et al. [22]. Dans la séquence de la caséine $\beta$, la lettre U correspond à la sérine phosphorylée. ( $\square$ ) correspond aux peptides produits lors de I'hydrolyse par la trypsine et la chymotrypsine de la caséine $\beta$ et (플 ceux résultant de l'hydrolyse par les peptidases des bactéries propioniques. Action de la chymotrypsine $(\nabla)$; et de la trypsine $(\nabla)$. 


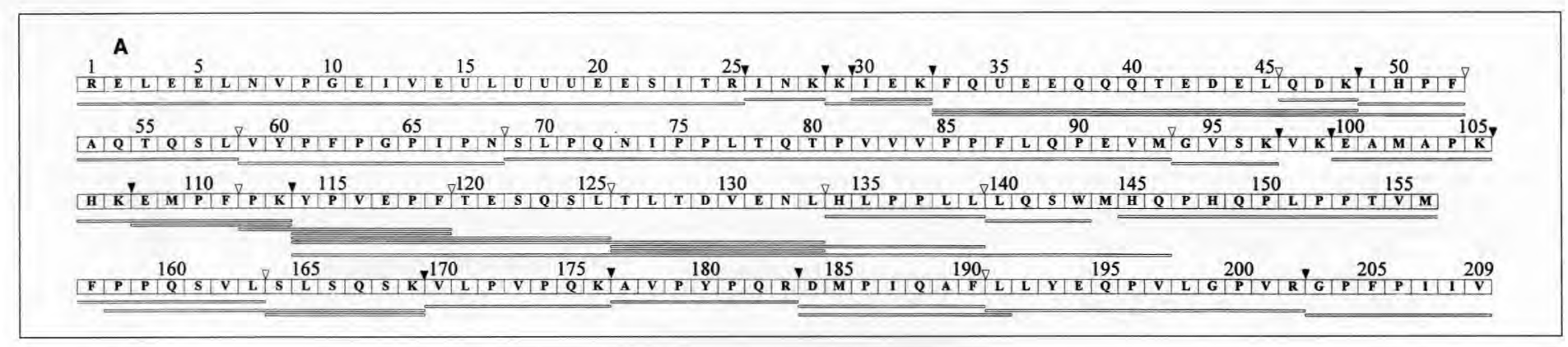

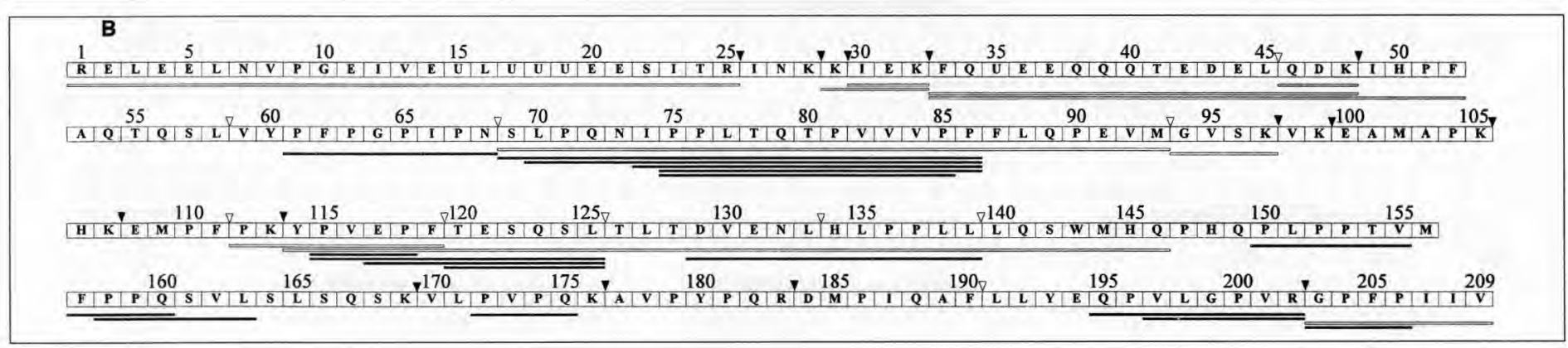

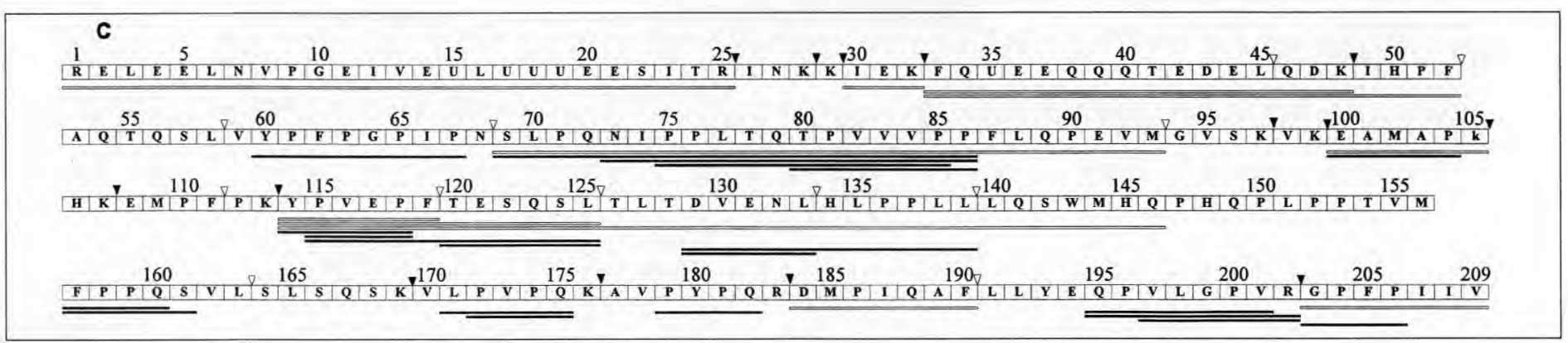




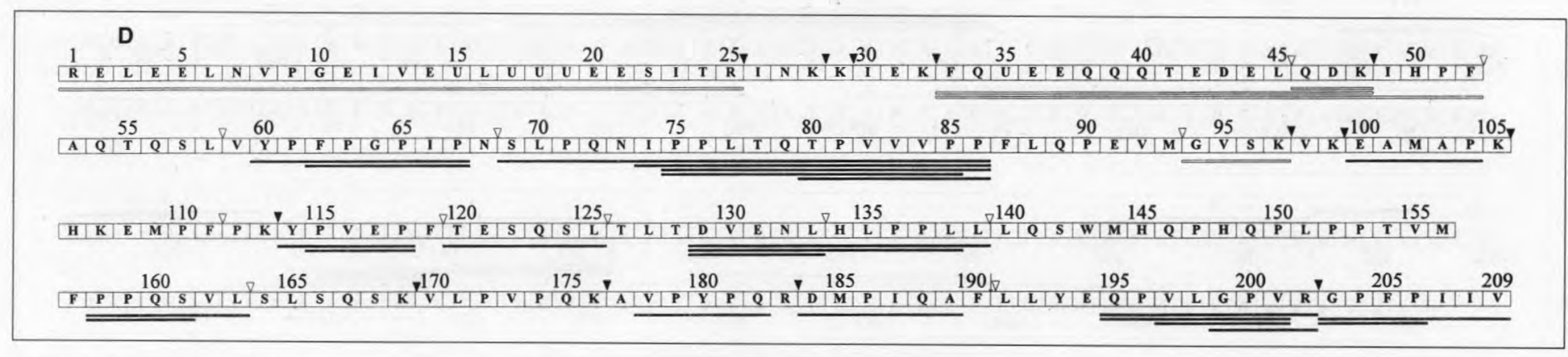

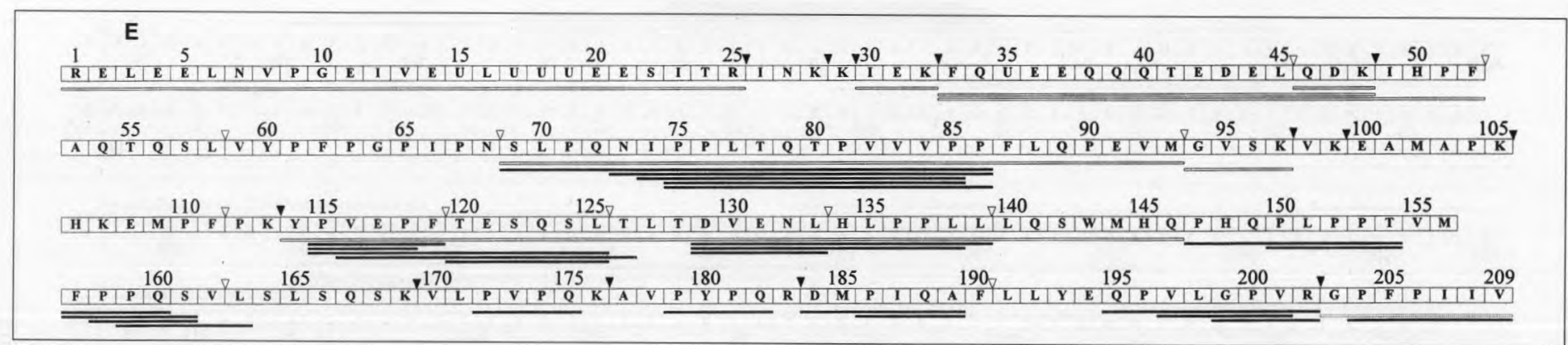


milk media. Furthermore, autolysis was strongly strain dependent and varied largely from 10 to $90 \%$ in both buffer and sodium lactate broth. In P. freudenreichii cells, autolysis appeared to be strongly induced by depletion of lactate [23, 24, 27, 28]. However, in contrast to $\mathrm{LAB}$ in Cheddar [48] and in Saint Paulin [6], direct evidence of autolysis in Emmental cheese was not established until recently [47]. Using immunoblotting analysis, Valence et al. [47] showed that autolysis of $P$. freudenreichii occurred very late during cold storage of Emmental and that its extent was limited. In industrial French Emmental cheeses, neither depletion of lactate nor loss of viability of PAB after $60 \mathrm{~d}$ of ripening was observed, suggesting a low frequency of autolysis by PAB [43]. It is likely that in Swiss-type cheeses with longer ripening times, the PAB could autolyse and release their enzyme pool. Thus, damaged cells of PAB were observed in the Italian cheese, Grana Padano, by scanning electron micrographs after eight months of ripening [5].

To appreciate the real impact of PAB in cheese is rather difficult because their growth begins when that of LAB has ended. The impact of LAB seems to be prominent since in most cases, they have a higher autolytic [47] and proteolytic activity [16] than the PAB strains in cheese. Thus, throughout ripening, reverse phase HPLC peptide profiles of juice or aqueous water extracts of Emmental cheeses showed a specific 'fingerprint' which appeared from the cold room stage and can be related to the prominent action of proteolytic enzymes from LAB starters (unpublished observations). The further modifications in the peptide profile induced by PAB is comparatively low. Quantitatively, the nitrogenous fractions produced by proteolysis (soluble $\mathrm{N}$ and non-protein $\mathrm{N}$ fractions) increased significantly during the warm room period, when PAB have not yet reached a sufficient population to participate significantly in proteolysis in cheese ( $<10^{7} \mathrm{cfu} \cdot \mathrm{g}^{-1}$ of cheese) [43], confirming the low impact of PAB in the secondary proteolysis in cheese. This was also observed in a non-Swiss-type cheese, Cheddar, with added PAB by Fernandez-Espla and Fox [12]. The addition of $P$. shermanii NCDO 853 at high levels to Cheddar (between $10^{7}$ and $10^{9} \mathrm{cfu} \cdot \mathrm{g}^{-1}$ of cheese) led to minor quantitative differences but no qualitative one in the peptide profile of cheese made with and without PAB.

Recent data obtained in our laboratory show that PAB utilize peptides produced by the peptidases and proteinases of LAB as well as most amino acids except Ala, Pro, Leu and Lys (unpublished results). This suggests either transport of peptides into the $\mathrm{PAB}$ cells and their subsequent hydrolysis by intracellular peptidases, or a turnover of these amino acids during PAB growth. Peptide and amino acid utilization may induce changes in the qualitative balance of peptides and amino acids potentially responsible for the flavour characteristic of Swisstype cheeses. It will be interesting to study whether this impact on proteolysis is more pronounced in the case of Swiss-type cheeses with long ripening periods in which the autolysis phenomenon of PAB cells may be more apparent, than in French industrial Emmental with its $60 \mathrm{~d}$ ripening time.

\section{CONCLUSION}

$\mathrm{PAB}$ appeared to be equipped with many of the enzymes necessary to produce amino acids and small peptides from caseins [21] with 11 different peptidases purified and characterized. However, in contrast to LAB, it is not possible to find the complete proteolytic pathway of casein degradation into peptide and amino acids in PAB. Even if a proteinase and one or two peptidases are distributed in the cell wall and can initiate casein hydrolysis, most of the peptidases are intracellular. Consequently, for further hydrolysis of casein derived peptides by intracellular enzymes, peptide transport systems are necessary. This is especially crucial since autolysis appears to be quite limited 
and the release of intracellular peptidases consequently weak. However, to our knowledge, no information on the peptide transport systems of PAB exists. There is a need to determine the nature and the size of the peptides which can be used by the cell and their transport mechanism. Moreover, the amino acids not used for protein turnover can be catabolized to aromatic compounds which contribute directly to the characteristic flavour of the cheese. It would be of interest to determine aminotransferase, decarboxylase, and deaminase activities implicated in the amino acid catabolism of PAB.

\section{ACKNOWLEDGEMENT}

We thank S. Lortal for helpful discussions and critical reading of the manuscript.

\section{REFERENCES}

[1] Addeo F., Chianese L., Salzano A., Sacchi R., Cappuccio U., Ferranti P., Malorni A., Characterization of the $12 \%$ trichloroacetic acid insoluble oligopeptides of Parmigiano-Reggiano cheese, J. Dairy Res. 59 (1992) 401-411.

12] Addeo F., Chianese L., Sacchi R., Spagna Musso S., Ferranti P., Malorni A., Characterization of the oligopeptides of Parmigiano-Reggiano cheese soluble in $120 \mathrm{~g}$ trichloroacetic acid/L, J. Dairy Res. 61 (1994) 365-374.

[3] Baer A., Influence of casein proteolysis by starter bacteria, rennet and plasmin on the growth of propionic acid bacteria in Swiss-type cheese, Lait 75 (1995) 391-400.

[4] Biede S.L., Hammond E.G., Swiss cheese flavor: I Chemical analysis; 11 Organoleptic analysis, J. Dairy Sci. 62 (1979) 227-248.

15] Cappa F., Bottazzi V., Bosi F., Parisi M.G. Caratteristiche di batteri propionici sviluppati in formaggio grana, Sci. Tech. Latt. Casearia 47 (1996) $405-414$

[6] Chapot-Chartier M.P., Deniel C,, Rousseau M. Vassal L., Gripon J.C., Autolysis of two strains of Lactococcus lacris during cheese ripening, Int. Dairy J. 4 (1994) 215-269.

[7] Dupuis $C_{+}$, Activités protéolytiques et lipolytiques des bactéries propioniques laitières. Ph.D. thesis, ENSA Rennes, France, 1994, 144 p.

[8] EI Soda M., Desmazeaud M.J., Bergère J.L., Peptide hydrolases of Lactohacillus casei: isolation and general properties of various peptidase activities, J. Dairy Res. 45 (1978) $445-455$.
[9] El Soda M., Macedo A., Olson N.F., Aminopeptidase and dipeptidylaminopeptidase activities of several cheese-related micro-organisms, Milchwissenschaft 46 (1991) 223-226.

[10] El Soda M., Ziada N., Ezzat N., The intracellular peptide-hydrolase system of Propionibacterium, Microbios. 72 (1992) 65-74.

[11] Fernandez-Espla M.D., Fox P.F., Purification and characterization of X-Prolyl dipeptidyl aminopeptidase from Propionibacterium shermanii NCDO 853. Int. Dairy J. 7 (1997) 23-29.

[12] Fernandez-Espla M.D., Fox P.F., Effect of adding $P$. freudenreichii subsp. shermanii NCDO 853 or Lactobacillus casei ssp. casei IFPL 731 on proteolysis and flavor development of Cheddar cheese, J. Agric. Food Chem. 46 (1998) 1228-1234.

[13] Ferranti P., Barone F., Chianese L., Addeo F., Scaloni A., Pellegrino L., Resmini P., Phosphopeptides from Grana Padano cheese: nature, origin and changes during ripening, J. Dairy Res. 64 (1997) 601-615.

[14] Floberghagen V., Sørhaug T,, Langsrud T,, Peptide hydrolase in propionibacteria, in: 20th International Dairy Congress, vol. F, Paris, 1978 , pp 477-478.

[15] Fox P.F., O'Connor T.P., McSweeney P.L.H., Cheese: physical, biochemical, and nutritional aspects, Adv. Food Nutrition Res. 39 (1996) $163-328$.

[16] Gagnaire V., Lortal S., Léonil J., Free active peptidases are detected in Emmental juice extracted before ripening in the warm room. J. Dairy Res. 65 (1998) 119-128.

[17] Gagnaire V., Pierre A.. Mollé D., Léonil J., Phosphopeptides interacting with colloidal calcium phosphate isolated by tryptic hydrolysis of bovine casein micelles, J. Dairy Res. 63 (1996) $405-422$.

[18] Kunji E.R.S., Mierau I., Hagting A., Poolman B., Koning W.N., The proteolytic systems of lactic acid bacteria, Anton. Leeuwenhoek 70 (1996) 187-221.

[19] Langsrud T., Reinbold G.W., Hammond E.G., Proline production by Propionibacterium shermanii P59, J. Dairy Sci. 60 (1977) 16-23.

[20] Langsrud T., Reinbold G.W., Hammond E.G., Free proline production by strains of propionibacteria. J. Dairy Sci. 61 (1978) 303-308.

[21] Langsrud T., Sørhaug T., Vegarud G., Protein degradation and amino acid metabolism by propionibacteria, Lait 75 (1995) 325-330.

[22] Lemée R., Gagnaire V., Maubois J.L., Strain variability of the cell-free proteolytic activity of dairy propionibacteria towards $\beta$-casein peptides, Lait 78 (1998) 227-240.

[23] Lemée R., Lortal S., Cesselin B., van Heijenoort J., Involvement of an $\mathrm{N}$-acetylglucosaminidase in autolysis of Propionibacterium freudenreichii CNRZ 725, Appl. Environ. Microbiol. 60 (1994) $4351-4358$. 
[24] Lemée R., Rouault A., Guézenec S., Lortal S., Autolysis of fifty seven strains of dairy propionibacteria, Lait 74 (1994) 241-251.

[25] Lortal S., Lemée R., Valence F., Autolysis of thermophilic lactobacilli and dairy propionibacteria: a review, Lait 77 (1997) 133-150.

[26] Monnet V., Nardi M., Chopin A., Chopin M.C., Gripon J.C., Biochemical and genetic characterization of $\mathrm{PepF}$, an oligopeptidase from $\mathrm{Lac}$ tococcus lactis, J. Biol. Chem. 269 (1994) 32070-32076.

[27] Østlie H., Floberghagen V., Reinbold G.W. Hammond E.G., Vegarud G., Langsrud T., Autolysis of dairy propionibacteria: growth studies, peptidase activities, and proline production, J. Dairy Sci. 78 (1995) 1224-1237.

[28] Østlie H., Vegarud G., Langsrud T., Autolysis of dairy propionibacteria in buffer systems, J. Dairy Sci. 78 (1995) 2315-2325.

[29] Panon G., Purification and characterization of a proline iminopeptidase from Propionibacterium shermanii 13673, Lait 70 (1990) 439-452.

[30] Perez Chaia A., Pesce de Ruiz Holgado A., Oliver G., Peptide hydrolases of propionibacteria: effect of $\mathrm{pH}$ and temperature, J. Food Prot. 53 (1990) 237-240.

[31] Pripp A.H., Tobiassen R.O., Stepaniak L., Sørhaug T., Endopeptidases and aminopeptidases from Propionibacterium freudenreichii ATCC 9614. Distribution and partial separation of intracellular fraction, in: Conferences and posters abstracts of the First International Symposium on Dairy Propionibacteria, Inra, Rennes, France, 1995, p. 66.

[32] Prost F., Chamba J.F., Effect of aminopeptidase activity of thermophilic lactobacilli on Emmental cheese characteristics, J. Dairy Sci, 77 (1994) 24-33.

[33] Quelen L.C., Dupuis C., Boyaval P., Prolinespecific activities of $P$. freudenreichii subsp. shermanii, J. Dairy Res. 62 (1995) 661-666.

[34] Sahlström S., Espinosa C., Langsrud T., Sørhaug T., Cell wall, membrane, and intracellular peptidase activities of Propionibacterium shermanii, J. Dairy Sci. 72 (1989) 342-350.

[35] Sahlström S., Langsrud T., Sørhaug T., Characterization of peptidase activities associated with cell-walls of Propionibacterium freudenreichii, in: Conferences and posters abstracts of the First International Symposium on Dairy Propionibacteria, Inra, Rennes, France, 1995, p. 65.

[36] Sasaki M., Bosman B.W., Tan P.S.T., Comparison of proteolytic activities in various lactobacilli, J. Dairy Res. 62 (1995) 601-610.

[37] Sasaki M., Bosman B.W., Iwasaki T., Tan P.S.T., The purification and characterization of a new oligopeptidase from Lactobacillus SBT2171, (submitted and quoted by Kunji et al. [18])

[38] Singh T.K., Fox P.F., Healy A., Isolation and identification of further peptides in the diafiltration retentate of the water-soluble fraction of Cheddar cheese. J. Dairy Res. 64 (1997) $433-443$.

[39] Steffen C., Eberhard P., Bosset J.O., Rüegg M., Biochemistry of cheese ripening, in: Fox P.F. (Ed.), Cheese: chemistry, physics and microbiology, vol. 2, Major cheese groups, Chapman \& Hall, London, 1993, pp. 83-110.

[40] Stepaniak L., Gobbetti M., Pripp A.H., Sørhaug T., Isolation and characterization of a $67 \mathrm{kDa}$ oligopeptidase from $P$. freudenreichii ATCC9614, Italian J. Food Sci. 10 (1998) $117-125$.

[41] Stepaniak L., Tobiassen R.O., Chuku I., Pripp A.H., Sørhaug T., Purification and characterization of a $33 \mathrm{kDa}$ subunit oligopeptidase from P. freudenreichii ATCC 9614, Int. Dairy J. 8 (1998) 33-37.

[42] Tan P.S.T., Pos K.M., Konings W.N., Purification and characterization of an endopeptidase from Lactococcus lactis subsp. cremoris Wg2, Appl. Environ. Microbiol. 57 (1991) 3593-3599.

[43] Thierry A., Salvat-Brunaud D., Madec M.N., Michel F., Maubois J.L., Affinage de l'emmental: dynamique des populations bactériennes et évolution de la composition de la phase aqueuse, Lait 78 (1998) 521-542.

[44] Tobiassen R.O., Pripp A.H., Stepaniak L.. Sletten K., Sørhaug T., Purification and characterization of an endopeptidase from Propionibacterium freudenreichii, J. Dairy Sci. 79 (1996) 2129-2136.

[45] Tobiassen R.O., Stepaniak L., Sørhaug T., Screening for differences in the proteolytic systems of Lactococcus, Lactobacillus and Propionibacterium, Z. Lebensm. Unters. Forsch. A 204 (1997) 273-278.

[46] Toonen M.Y., Ledeboer A.M., Isolation and characterization of the gene encoding proline iminopeptidase from $P$. shermanii, in: FEMS Microbiol. Review Special issue, vol 12, 1993, p. 76 (D17).

[47] Valence F., Richoux R., Thierry A., Palva A., Lortal S., Autolysis of Lactobacillus helveticus and Propionibacterium freudenreichii in Swiss cheeses: first evidence by using species-specific lysis markers, J. Dairy Res. 65 (1998) 609-620.

[48] Wilkinson M.G., Guinee T.P., O'Callaghan D.M., Fox P.F., Autolysis and proteolysis in different strains of starter bacteria, J. Dairy Res. 61 (1994) 249-262. 